\title{
Le chariot à main iranien. Modes de transport, rationalité technique et logique d'État
}

Didier Gazagnadou

\section{(2) OpenEdition}

12 Journals

Édition électronique

URL : https://journals.openedition.org/tc/357

DOI : $10.4000 /$ tc. 357

ISSN : 1952-420X

Éditeur

Éditions de l'EHESS

\section{Édition imprimée}

Date de publication : 1 juillet 1999

ISSN : 0248-6016

\section{Référence électronique}

Didier Gazagnadou, «Le chariot à main iranien. Modes de transport, rationalité technique et logique d'État », Techniques \& Culture [En ligne], 33| 1999, mis en ligne le 26 octobre 2005, consulté le 29 septembre 2022. URL : http://journals.openedition.org/tc/357 ; DOI : https://doi.org/10.4000/tc.357

Ce document a été généré automatiquement le 29 septembre 2022.

Tous droits réservés 
Le chariot à main iranien. Modes de transport, rationalité technique et logique d'État

Didier Gazagnadou 